\title{
VIRTUAL RECREATION OF REYNALDO DIERBERGER LANDSCAPE PROJECTS FOR UFRRJ CAMPUS
}

\author{
Ana Paula R. Araujo ${ }^{1}$, Claudio Antônio S. L. Carlos ${ }^{1}$, Wellington Mary ${ }^{2}$, Beatriz Martins ${ }^{3}$; Evellyn Santana ${ }^{3}$; Joanna Ribeiro ${ }^{3 *}$ \\ ${ }^{1}$ UFRRJ, Dep. de Arquitetura e Urbanismo, Programa de Pós-graduação Patrimônio, Cultura e Sociedade, BR 465 km 7 , \\ Seropédica, Rio de Janeiro/RJ, Brasil - (ana.r.araujo, claudio.limacarlos) @ gmail.com \\ ${ }^{2}$ UFRRJ, Dep. de Arquitetura e Urbanismo, BR 465 km 7, Seropédica, Rio de Janeiro/RJ, Brasil - (wellmary01@ gmail.com) \\ ${ }^{3}$ UFRRJ, Graduação em Arquitetura e Urbanismo, BR 465 km 7, Seropédica, Rio de Janeiro/RJ, Brasil - (martinsbea20, \\ santevellyn, joanna.dos.santos.ribeiro) @gmail.com
}

KEYWORDS: Digital Heritage, Virtual Recreation, Computer-based visualization, 3d Modeling, Landscape Heritage, UFRRJ.

\section{ABSTRACT}

This paper presents some current results of the research, which proposes a virtual recreation of Reynaldo Dierberger original project for the Seropédica campus of UFRRJ, located in Rio de Janeiro State, Brazil. The gardens, as well as the original architectural ensemble, in neocolonial style, have been legally protected in 2001. The group of researchers faced a triple challenge to make the virtual recreation. The first one concerns the identification of what was designed and not built, based on original hand-made drawings filed in the Document Conservation Laboratory of UFRRJ (LabDOC) and other university departments. The second challenge concerns the interpretation of the elements from English Garden design principles that emerged in the 19th century and were developed in Brazil by European landscapers such as Glaziou (1828-1906). The third one concerns making design drawings digital to elaborate $3 \mathrm{~d}$ models considering a group of digital graphic tools available and also the application of Sevilla Principles (2011). It is important to mention that some of the research activities were impaired by the COVID-19 pandemic.

\section{INTRODUCTION}

This paper presents some current results of the research that propose a virtual regeneration of Reynaldo Dierberger's original project for the Seropédica campus of UFRRJ, located in Rio de Janeiro State, Brazil. (fig. 1). The gardens, as well as the original architectural ensemble, in neocolonial style, have been legally protected in 2001.

The research adopted the Florence Charter (1982) and Juiz de Fora Charter (2010) as theoretical references highlighting the concept of "historical garden". It also adopted international referenced texts and charters in heritage documentation of scientific knowledge that includes the computerized visualization techniques for reading and interpreting ideas and intentions to the analyzed projects, the Principles of Seville (2011) and others, such as Tostrup (1999), Sainz (2005), Boutinet (2005), utilized to interpret drawings' contents.

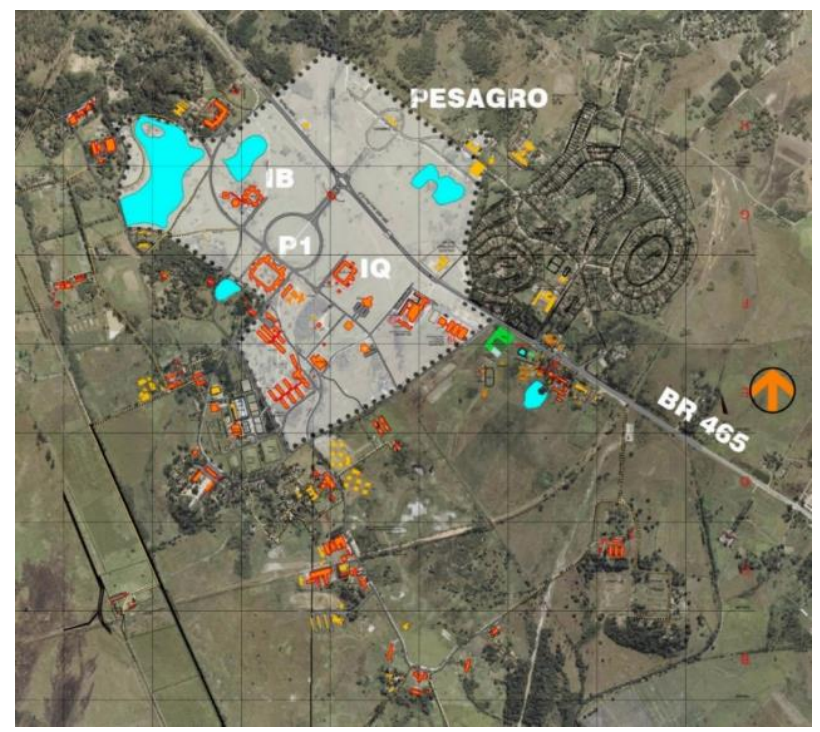

Figure 01. Protected area. Source: adapted by INEPAC's process number E-13/001.540/98, fl. 34

The collection of hand-made drawings for the campus landscape design is currently in the process of identification, cataloging, and preventive conservation by LabDOC. That was created in 2013 with resources provided by the Rio de Janeiro Research Support Foundation (FAPERJ, in Portuguese).

The article was structured in three parts. The first one presents the historical aspects related to the origins of the English garden, as a design language that influenced Reynaldo Dierberger in the project of the Seropédica campus. In order to complete this step, there is a brief approach to the concept of the historical garden, presented by the Florence Charter (1982) and Juiz de Fora Charter (2010). The second step proposed is dedicated to a brief consideration of the concepts of design, graphic representation, and computerized visualization. The third part presents the results obtained by the research so far.

\section{THEORETICAL APPROACH: ENGLISH GARDEN LANGUAGE AND HISTORICAL GARDENS CONCEPT ADOPTED BY REYNALDO DIERBERGER}

In Brazil, especially in the city of Rio de Janeiro, the public garden emerged as a true symbol of civility, an oasis, considering unhealthy urban conditions, from its foundation until the 18th century, when it became the capital of the colony, in 1763. In this context, the Passeio Público (1779-1783) was 
the first public garden built in the city. It has been designed by Mestre Valentin to replace the "pestiferous" Boqueirão Lagoon, a traditional waste disposal site. It is noteworthy that nowadays the garden has the appearance imposed by the reform undertaken by the French landscaper Auguste François Marie Glaziou, in 1862. The reform substituted the straight paths and flowerbeds, in a French style, to adopt the English garden organic characteristic design (Terra, 2013, p.116).

Gardens emerged in Europe at the end of the 18th century, in order to be incorporated into the landscapes of cities. They were constituted in counterpoint to the transformations of urbanization to simulate natural environments. In the 19th and 20th centuries, the art of gardens, gardening and plant collection was marked by the publication of books, magazines, and specialized publications that highlighted the art of working with nature. Initially, cultivated in the back areas of middle-class residences, bound on the outskirts of cities, the gardens gained an urban dimension, originating, among others, public gardens and parks, a direct counterpoint to the unhealthiness and noise of cities (Terra, 2013, p. 61).

In Brazil, Glaziou's landscaping was characterized by the use of mixed characteristic languages of the English garden and French gardens. He contributed to imprint its mark on several landscape projects in Rio de Janeiro. In 1868, Glaziou renovated the gardens at Quinta da Boavista. He used these characteristics also in other projects in Rio de Janeiro, with emphasis on Campo de Santana, in partnership with Francisco José Bicalho, designed originally for the public service. However, there are few examples of the English Style of Landscaping in Brazil, but in summary, what should be observed are the strong characteristics of the line of sight that highlights points of interest, such as buildings, exotic trees, among other aspects (Barbin, 1999). Another striking feature of this style is the prioritization of the organic sinuosity of the paths, such as leafy trees forming small woods along with extensive lawns, as well as alleys formed by trees of floristic interest with vibrant colors, in addition to the constitution of lakes, islands, streams, artificial waterfalls, etc.

In the 20th century, landscaper Reynaldo Dierberger (18931940) kept alive the tradition of the English garden in Brazil in his projects. In addition to these formal repertoires, some unpaved alleys are observed, on a dirty floor to characterize a rural environment. The original landscape design still predicted a monumental entrance porch, studied in two versions identified in the collection of drawings under the care of LabDoc. The element would provide the visitor who entered the campus the visual framework of the central body of the Central Pavilion (fig. 2).

On the other hand, it is observed that the organic landscape layout proposed by Dieberger contrasts with the model of implantation of the main pavilions of the campus (Central Pavilion, Institutes of Biology and Chemistry). The buildings have a rigid and formalistic neocolonial shape, which formed two orthogonal axes that highlight them in the projected landscape (fig. 3). The generosity of free spaces between these buildings maintains the rural aspect intended in its creation, like a large farm, which must be considered in its conservation.

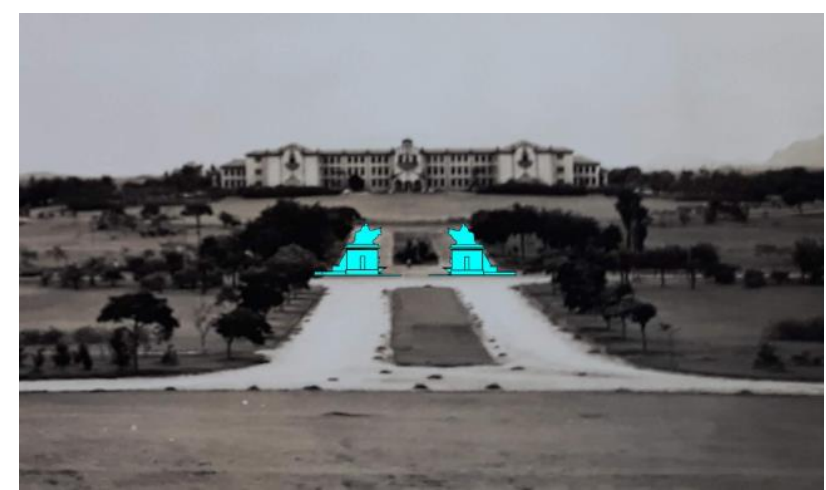

Figure 02. Photomontage of the porch project. Elaborated by Scientific Initiation fellows Joanna Ribeiro; Beatriz Martins, Evellyn Santana

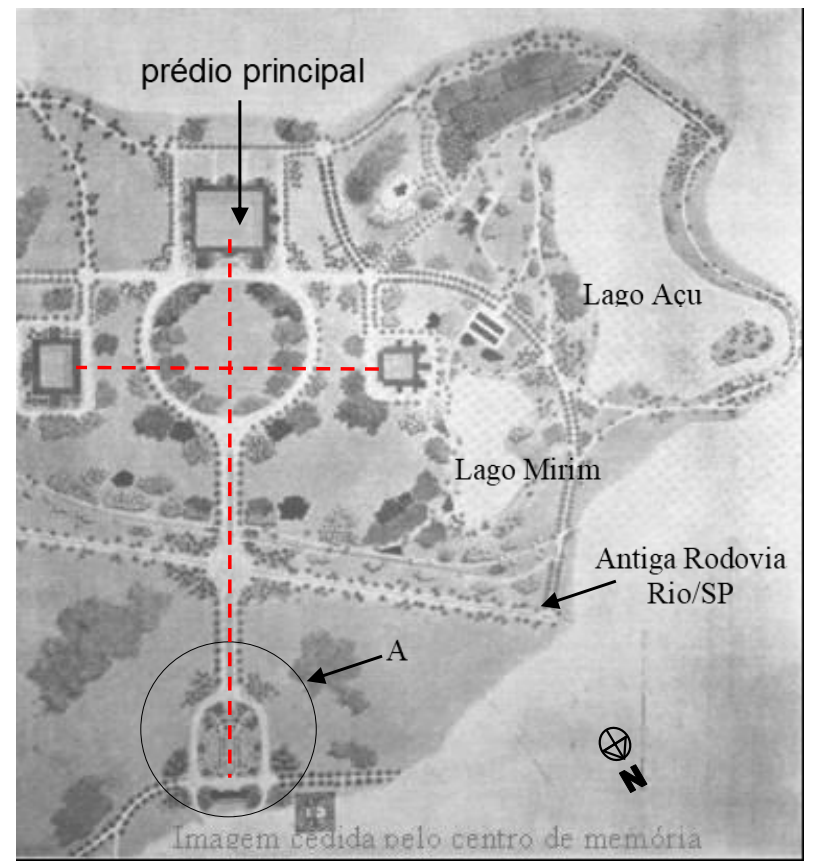

Figure 03. Masterplan of the landscaping proposed by Reynaldo Dierberger, highlighting the axis between the main buildings cut by the Old Estrada Rio / SP Source: Memory Center of UFRRJ

Because of the historical importance of landscaping developed since the 19th century, the concept of "historic garden" was enshrined in the Charter of Florence (International Committee of Gardens and Historical Sites - Icomos, 1982). The document expresses the international concern with the integration of gardens into the list of issues related to cultural heritage. Subsequently, the Charter of Brazilian Historical Gardens (Charter of Juiz de Fora - 2010) reinforced the issue of historical gardens to the Brazilian reality, highlighted by the Charter of Florence (1982).

The Florence Charter (1982) defined a historic garden as "an architectural and vegetal composition that presents public interest from the historical and artistic points of view". In this sense, it should be understood as a 'monument', highlighting, however, that it is an architectural composition, whose "constituent material is mainly of vegetal origin, consequently alive, and as such perishable and renewable". The document emphasized that "(...) its aspect results from a perpetual balance between the cyclical movement of the seasons, the development and decay of nature and the artistic composition desire that tends to perpetuate its condition." Regarding conservation, the 
document recommends in Article 3 that: "As a monument, the historic garden must be safeguarded following the spirit of the Venice Charter (1964). However, as an "alive monument", his safeguard stems from specific rules (...) "that interfere in the architectural composition of the historic garden, such as "its plan and the various profiles of the land; the vegetal masses: essence, volume, chromatic composition, space, and respective heights; built and decorative elements, moving or stagnant waters that reflect the sky".

Besides, the document recommends that "any maintenance, conservation, restoration or reconstitution operation of a historic garden or one of its parts must take into account, simultaneously, the set of all its elements". It draws attention to the fact that any "differentiation of treatments" can alter the overall effect of the garden.

The Florence Charter (1982) strongly recommends continuous maintenance of the gardens because of their living plant nature. Therefore, the maintenance works must be "(...) conducted through of occasional substitutions and, in the long term, by cyclical renewals (cutting and replanting of already formed species)." It also recommends that "(...) the choice of trees, shrubs, plants, and flowers for periodic replacement" should be carried out "according to the established and recognized uses for different botanical and cultural zones, to maintain and investigate species source."

For the elements of architecture, sculpture, and fixed or mobile decoration that form an integral part of a historic garden, the document recommends that "they should not be removed or moved from their places, except for the requirements of their conservation or restoration. The replacement or restoration of elements at risk must be carried out under the principles of the Venice Charter, indicating the date of any replacement." It also highlights that the historic garden "(...) must be kept in an appropriate context. Any modification of the physical environment that puts the ecological balance at risk must be banned", that is, the "(...) set of infrastructures, whether internal or external (plumbing, irrigation systems, roads, parking lots, enclosures, surveillance devices, exploitation, etc)".

Juiz de Fora Charter (2010) endorsed the concept of the "historic garden", established by the Florence Charter (1982), establishing specificities related to the Brazilian cultural reality. The document highlighted that: “(...) in the Brazilian reality, they are equivalent to historical gardens in symbolic and affective importance, places of encounter and conviviality, such as parks, gardens, and tours of historic cities and large metropolises (...)". Regarding the notion of the historical monument, the text of the Charter also mentions that it " $(\ldots)$ is not restricted to the stricto sensu vision of built assets by man but covers the landscape and other examples of its interaction with nature".

\section{METHODOLOGICAL PROCEDURES: LANDSCAPE DESIGN, GRAPHIC REPRESENTATION, AND COMPUTERIZED VISUALIZATION}

The historical documentation, especially the architectural, urban, and landscaping design drawings elaborated for the construction of cultural assets, brings important information that contributes, especially, to the digital reconstitution of the intentions of their respective designers.

Through the graphic representation of the project, different analyses of urban and landscape architectural projects were possible. They provide us with a concrete possibility to understand what was intended in the past and how it has been appropriated to conserve, at present.

Faced with the task of interpreting iconographic and cartographic sources, which in our research include a set of illustrations of watercolored perspectives and technical drawings, it was necessary to revisit the meaning of the graphic representation of architectural, urban, and landscape projects. Based on principles presented by Sainz (2005), drawing is not only an appropriate instrument or means to describe the details of a work. It reflects ideas and architectural realities on the graphic plane. This is because, in addition to being a work tool (instrumental dimension), it is also capable of provoking emotions (expressive dimension). When both dimensions manifest simultaneously, it is considered a masterpiece. From a project perspective, drawing has the function of anticipating a future reality and, therefore, it is "full of promises and many open questions" (Vagnetti apud Sainz, 2005).

Concerning the "promises", the architecture, urbanism, and landscaping design drawings can be elaborated seeking to seduce and convince the receiver of the information (clients, jurors, end-users, etc.). The design solution represented must respond satisfactorily to the problem or situation of the project (Tostrup, 1999). This characteristic of project design corresponds to the definition presented by Boutinet (2002), in which the project in contemporary society is the conduct of temporal and spatial anticipation that guides development and improvement actions. It contains a real (existing) and an ideal (projected) space, in a temporal perspective (past / present / future). It reaffirms its preliminary nature, being incomplete and always presenting the positive side, that is, it embodies promises of gains and advantages.

About the "open questions", the design is by nature fragmented, static, and constant. It can preliminarily simulate the direct experience, which means only through visual perception, and is therefore not able to simulate the real experience.

To build the knowledge of a given cultural asset, it is necessary to use a diverse set of sources, so that information is complemented or compared since only the drawing hides several complementary data for greater detail and depth.

Regarding the relationship between graphic and architectural categories, Sainz (2005) states that there is no direct relationship between both, because a particular architecture does not require a particular type of design, nor does a particular type of design cause a particular architectural style. But it is the creator/designer/draftsman who establishes a stylistic relationship, which is expressed in the drawing.

About the graphic elements, we can say that every drawing supposes abstraction. There are different degrees of iconicity [Luesch-Reis, 1991] established between the object and its representation, that is, between the image presented and the icon that it evokes. The study of abstraction and iconicity is important because it regulates our ability to interpret and indicates the level of detail of the $3 \mathrm{~d}$ model. Greater abstraction causes more gaps in interpretation. Moles (1979) establishes a scheme with twelve degrees of abstraction/iconicity, classifying the three-dimensional model in contour, perspective and situation as the one with the highest degree of iconicity. Moles (1979) adds that there are other characteristics for the interpretation of different iconic species, such as the degree of figuration/abstraction, the degree of complexity, the degree of occupation of the visual field, the thickness of the plot or grain, the technical qualities of the system's projection (orthogonal, axonometric and conical), graphic variables (color, texture, light-shade, brightness), aesthetic dimension and degree of standardization. All these variables assist the description of iconographic and cartographic sources, as well as in the decision of what graphic representation must be adopted in the computerized visualization of UFRRJ's landscape heritage.

Different graphic techniques can be used. Manual techniques, such as pencil, ink, watercolor, or digital ones (vector drawing or bitmap) can influence the ability to read and interpret 
information. The quality of the representation varies according to attributes. The technical attributes, such as intelligibility, legibility, accuracy, and structure, the informative attributes, such as clarity, objectivity, economy, and completeness, and the expressive attributes, such as prominence and enhancement, interfere in the communicative and expressive quality of the graphic elements of the project's representation. The intelligibility of architectural illustrations means "what can be known by thought and not by meaning" (Ferreira, 1985, p. 774). Its interpretation depends on the decoding capacity, the hierarchies of information, the prepared receivers, the type of image finishing, and the congruence with which message is understood from the signs that are articulated in an adequate hierarchy considering the purpose of communication (Gruszynski, 2006, p. 6-7). Legibility depends on the technical quality of support and materials used, the contrast of the figure and background, and the relationship between image and surroundings. Highlighting and appreciating the main aspects of design in graphic representation are attributes that point out the reading to the most relevant aspects through aesthetic and emotional appeal.

In general, we consider that people who already have a repertoire for their understanding, built from lived experiences or culture, interpret the drawings according to their intentions.

Another factor that influences the quality of the images concerns the quality of the digitization of the originals. The National Council of Archives has built a series of recommendations for digitizing archival documents (National Archives, 2010) that includes a model for verifying the quality of the digital representative and its derivatives. In this way, they are emphasized as important aspects of the digital matrix (highresolution representatives), its derivative (low-resolution representative), and its processed derivative (edited in an image editing program): the format of the original and the digital matrix; the color mode, cropping, rotation, inversion, slope, sharpness, interference with lines, pixelization, histogram, contrast, tonal values, and graininess.

For the virtual re-creation of Dierberger's unrealized landscaping projects for UFRRJ, it was necessary to digitize the paper-based drawings available at LabDOC. To this end, it was considered that the digital representative of posters, prints, and drawings must follow what is recommended: minimum resolution of $300 \mathrm{dpi}$, scale 1: 1, with a black margin of $0.2 \mathrm{~cm}$ around the document, 24 bits ( 8 bits per color channel), RGB color model, with gray chart or colors for adjusting levels (preferably). (National Archive, 2010, p. 17). Other aspects are also important in document management: backup copies (at least two), locations and types of storage (computer, external hard drive, cloud storage), preservation of digital files (formats compatible with new reading tools), copyright, levels of access (unrestricted, controlled, restricted) and availability (of public or general interest with availability without request, by request), secrecy (reserved, secret, top-secret).

Once the landscape design drawings were digitalized, the research sought theoretical and methodological support in the heritage documentation for the elaboration of the virtual recreation. Virtual recreation is a technique that involves the use of a virtual model to visually recover a building or object made by humans at a given moment in the past from physical evidence and through comparisons based on scientific techniques used in history, in archeology, or other areas of knowledge (Seville Charter, 2009).

The research applied the principles of the London Charter: Principle 1 - Implementation - the guidelines were defined in the working plan considering the general and specific objectives. In the first stage, we read specific bibliography regarding heritage landscaping and gardens, heritage documentation (photography), and guides and manuals for heritage documentation. In the second stage, we selected the landscape design drawings (watercolors and technical drawings) available at LabDoc / UFRRJ. They were digitized by highresolution photography techniques and post-processed by image edition and computer-aided design applications. In the third stage, there were carried out the three-dimensional modeling of the buildings (P1, IQ, IB, and Pesagro), gardens (internal garden of $\mathrm{P} 1$, gardens of the central construction site), and entrance porch designs. Then, we started to model the non-executed elements (garden of P1, gardens of the central construction site of Pesagro, two porch projects). In the fourth stage, we prepared images to disseminate in scientific articles.

Principle 2 - Objectives and methods - it was defined that computerized visualization, using virtual recreation, would be the only possible and adequate method for the comparison between what is projected and constructed. This is because since several projects were not built, it would not be possible to proceed with virtual archaeology, nor a virtual restoration, virtual anastylosis, and virtual reconstruction. After all, there is no physical evidence available.

Principle 3 - Research sources - to identify the authorship and the represented objects, we used marks in the drawings. They guarantee the identification, selection, structuring, documentation, and evaluation of all sources to ensure intellectual integrity. We used the methodology of reading and interpreting visual sources explained above to enable the identification and description of the landscape, elements considering the English style of the gardens, and decorative elements of the neoclassical style.

Principle 4 - Documentation - the research is still developing images and descriptions capable of providing sufficient information to understand the methods and results of computerized visualization. It includes: the documentation of information rights; research sources (provenance); the documentation process (scheduled); visualization methods with a description of the result; documentation of the relationships between elements and the reasoning of the hypothesis elaboration; documentation formats considering the most appropriate and available means for dissemination and documentation of the criteria and ontologies for indexing and retrieving information.

Principle 5 - Sustainability - the methods for archiving were defined to guarantee the reliability and preservation of computerized visualizations in long term. A metadata system used for archiving follows the instructions of the National Archives (2010).

Principle 6 - Access - we intend to disseminate the study at the LabDOC page hosted by the university website.

The research sought interdisciplinarity between the field of architecture and urbanism, landscaping, and agronomy. A multidisciplinary team works sharing information through periodic meetings. The digital data was archived in the cloud hosting space to enable access for all timework.

In order to define the level of detail, resolution, accuracy of digital modeling, the team considered the quality of information available. We used the as-built drawings vector drawings (Figure 04), elaborated with direct techniques for the acquisition of geometric data (measuring tape, sketches), ceded by the Sustainable Management Center - NGS of UFRRJ, and digital photos captured by the teamwork. For the modeling of the projected elements, the original technical drawings were photographed and digitized with the aid of computer-aided design to guarantee geometric and dimensional precision. In the LabDoc collection, there were no plan and section drawings of the porches, only frontal views. In this way, some ornaments were modeled after the buildings. Unfortunately, we had no 
access to the original design drawings of the Pesagro building, and we couldn't make close-range photogrammetry because of Coronavirus pandemic protocols of social distance until now.

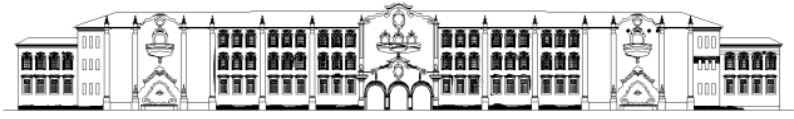

Figure 04. CAD drawing of the main facade of P1 building (Source: Sustainable Management Center - NGS, elaborated by undergraduate students of Architectural and Urbanism bachelor of UFRRJ).

We considered that the level of detail in the modeling of existing natural elements must consider at least the identification of species (popular and scientific name), their physical characteristics (description of the species, uses, forms of cultivation, dimensions, and photo), and spatial organization. Photos were used to produce information about the species and to guide the modeling. The team is studying the possibility of using three-dimensional models with a lower level of detail to model natural elements identified in the watercolors since it is not possible to identify all species with precision. In addition, we are facing the difficulty of accessing free three-dimensional models of vegetation by which is possible to identify the species.

Concerning authenticity, the research foresees in its modeling procedures the distinction between existing and projected elements, applying representations with different levels of accuracy. Having in mind the importance of the research and its guarantee of historical accuracy, the team searched for photographic records from different periods to understand changes comparing the design and the construction. It is also necessary to search for interventions in buildings and gardens in administrative documentation. However, due to the COVID-19 pandemic, access to documentation was made impossible, making it difficult to record different stages and conservation status.

We adopt free digital graphic tools for digital modeling. We elaborated a library of digital models so that the team could reuse the ornaments in the different buildings.

For scientific transparency, we intend to prepare a report that describes the process of constructing the three-dimensional model, making it available for testing by other professionals. Also, to be transparent, the documentation will include the objectives, the methodology, the techniques, the justifications, the origin, the characteristics of the research sources, the results, and the conclusions.

The project databases are also intended to be made available, once the documents themselves are the metadata. For the registration and storage of the generated digital files, it is necessary to register the metadata (Arquivo Nacional, 2010) and data for archiving (Arquivo Nacional, 2001) in database spreadsheets as shown in table 1 . The digital files were identified considering a numerical scheme (000), lowercase letters (xxx), without special characters and spaces, including information for easy identification and retrieval: date of capture, page number, sequencing of broken images. For example: 2014_DetalheFrontãoEntradaPrincipal_folha01-01.jpg.

\begin{tabular}{l|l}
\hline \multicolumn{1}{|c|}{ METADATA } & DATA FOR ARCHIVING \\
\hline ID digital substitute & Subject code \\
\hline $\begin{array}{l}\text { Physical dimensions of the } \\
\text { original }\end{array}$ & Subject abstract \\
\hline Reference code of original doc. & Document data: number \\
\hline Creation date & Date of the document \\
\hline Responsible for the creation & Species (letter, drawing, etc) \\
\hline Modification date & Sender (name and acronym of the \\
\hline
\end{tabular}

\begin{tabular}{l|l} 
& original organ) \\
\hline Responsible for the modification & $\begin{array}{l}\text { Receiver } \\
\text { Classification code for the } \\
\text { subject (040- Property; 041 - } \\
\text { Real State; 044 - Inventory) }\end{array}$ \\
\hline Illumination system & \\
\hline Archive format & \\
\hline Pixels (width x height) & \\
\hline Color depth & \\
\hline $\begin{array}{l}\text { Color mode (bitonal, grayscale, } \\
\text { RGB, CMYB, etc) }\end{array}$ \\
\hline Linear resolution (dpi ou ppi) \\
\hline Archive size \\
\hline ICC Profile \\
\hline Capture software \\
\hline Processing Software \\
\hline Operational system \\
\hline Hash (checksum) \\
\hline Source: Arquivo Nacional, 2010, p.18, 2001, p.17.
\end{tabular}

The research didn't require any training of the team because scholarship students used their knowledge of three-dimensional modeling learned in the topic of computer science applied to architecture and urbanism, which is part of the curriculum of the Architecture and Urbanism bachelor at UFRRJ. The evaluation of the model considered the geometric precision of the elements at the expense of the specialty of the result and will be carried out by the team members along with the modeling procedures.

\section{PARTIAL RESULTS}

To execute a computerized visualization of the landscape design, we opted for virtual recreation to help the interpretation of Dierberger's design intentions. Virtual recreation is defined by the Principles of Sevilla (2011) as being "a virtual model to visually recover an archaeological site at a given moment in the past, including material culture". The virtual recreation must be elaborated considering the principles of interdisciplinarity, purpose, complementarity, authenticity, historical rigor, efficiency, scientific transparency, training, and evaluation. The method of computerized visualization has not been established $a$ priori. We opted for three-dimensional photorealistic models of the existing elements and non-photorealistic models of unconstructed elements to elaborate interpretation hypotheses. This is because the research sources available, that is, the drawings and watercolors do not accurately inform the construction of materials and textures. The use of CAD bases provided by the Sustainable Management Center (NGS), from UFRRJ, was fundamental for the three-dimensional modeling of buildings. The plan altimetric survey prepared by professors and technicians from the Engineering Department of UFRRJ was also used for the modeling of the terrain, extracted from highresolution aerial photography. A cartographic base was also used in the scale 1: 10,000 with level curves in 5 to 5 meters of the Municipalities of Seropédica and Itaguaí, elaborated with an aerial photo of the Base Aerofotogrametria e Projetos SA, scale 1: 30.000, flight of July 2005, georeferencing and correction of Ambigis Ltda. The perimeter of Seropédica campus was extracted from the perimeter map projected in 1944, on a scale of 1: 25,000, by the Geographical Service Directorate (Brazilian Army provided by the UFRRJ Engineering Department) (fig. 05). To identify the limits of the protected area, we used the situational plan, scale 1:5000 inside INEPAC process E-18 / 001.540 / 98 of $11 / 27 / 1998$, pages 30 to 34 . 


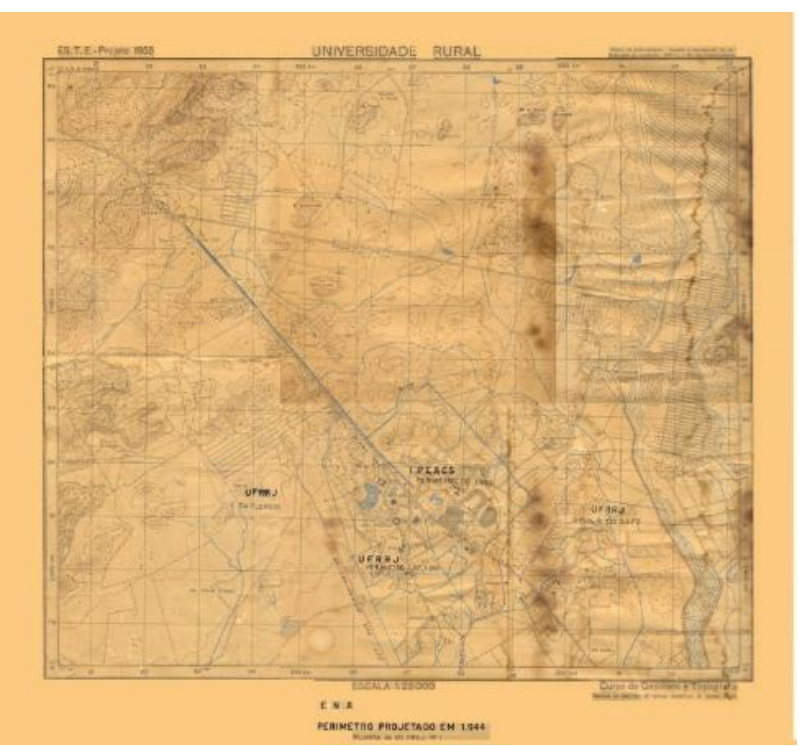

Figure 05. Map of the Perimeter of UFRRJ's Seropédica campus (1944). Source: UFRRJ Engineering Department.

For three-dimensional modeling of the unconstructed projected elements of the Dierberger project, the drawings of the internal garden of the Central Pavilion, the internal garden of Pavilion 2, the front view of the entrance porch of the campus, the view of the porch with the lions, watercolors were provided by the UFRRJ's LabDOC (Fig. 06 and 07).

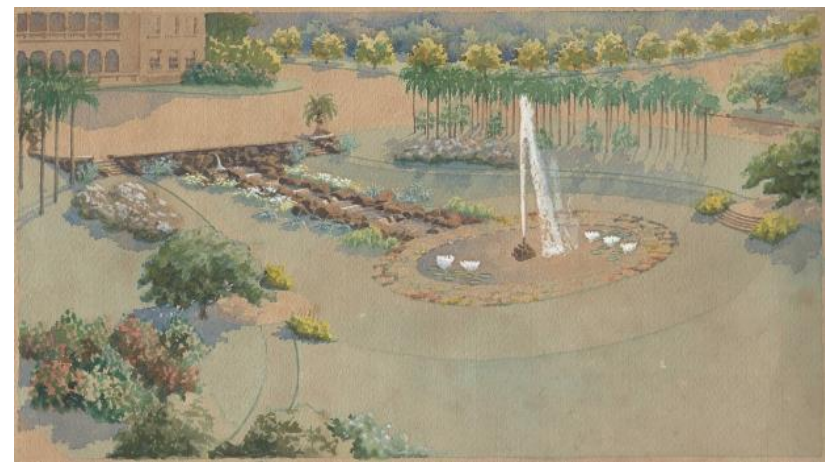

Figure 06. Watercolor 01 of Dierberger design for Pesagro gardens. Source: LabDOC/UFRRJ documentary collection.

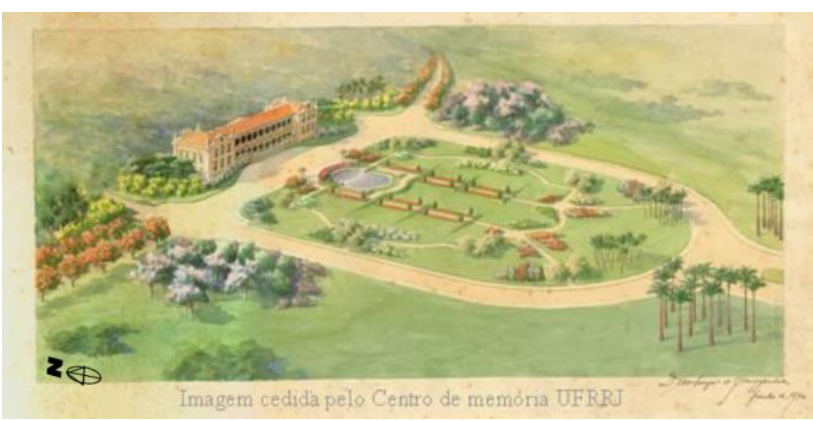

Figure 07. Watercolor 02 of Dierberger landscape design for around the Pesagro building, projected by architect engineering João Moreira Maciel (1958). Source: LabDOC/UFRRJ documentary collection.

For the modeling of the main porch, it was necessary to edit the scanned image. With the support of an image editing tool, the rectification was done using a perspective cut-out command (perspective in crop tool). We also removed the color (desaturate) and increased the contrast (brightness/contrast) between the black lines and the gray background. With that, it was possible to draw with CAD tool over the image. Since the project is symmetrical, considering a vertical axis in the center of the passage arch, we designed the left side because the image presents more visible details and we mirrored to the right side. Technical drawings of other buildings' details were used to model the ornaments (figs. 08).
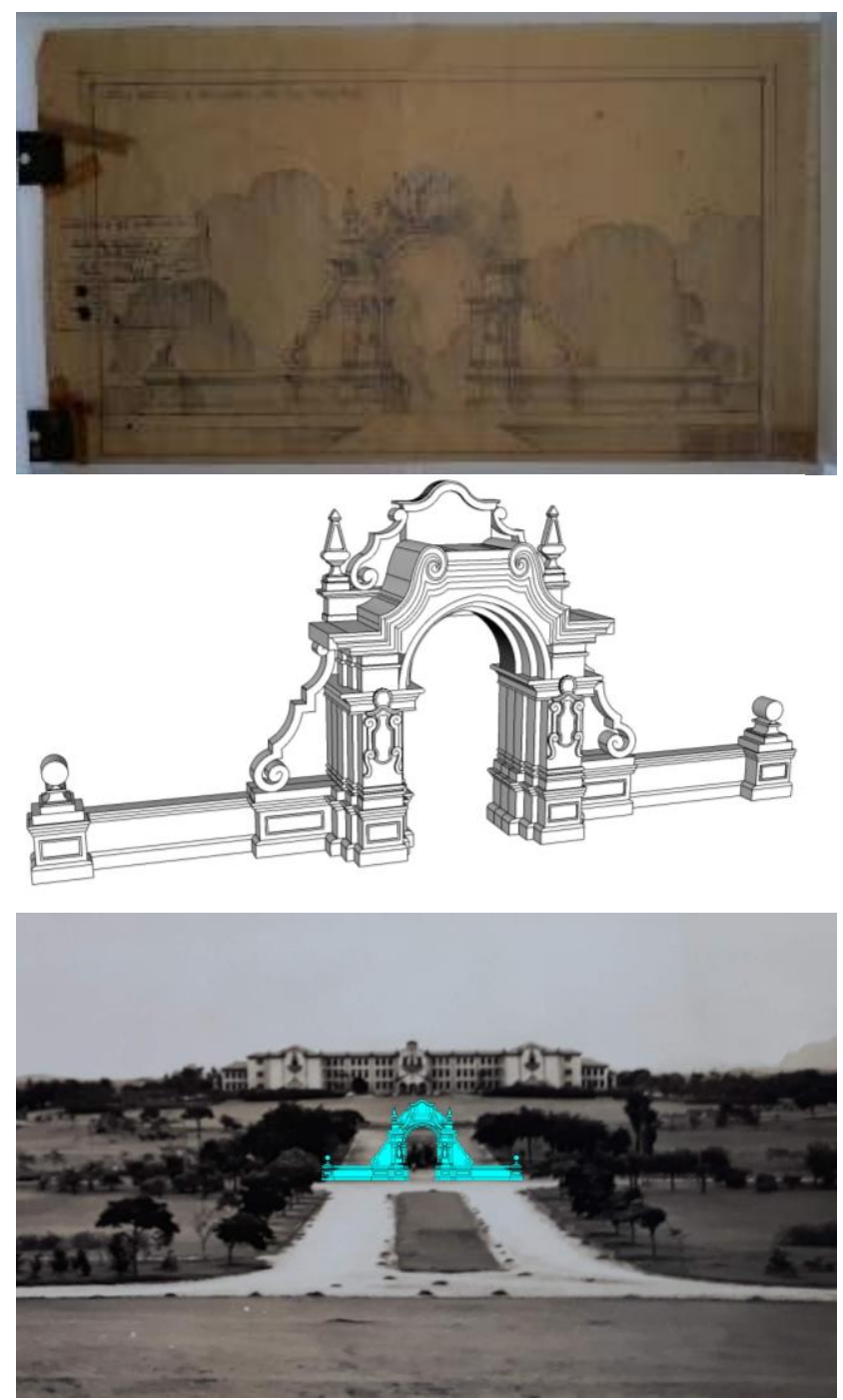

Figure 08. Frontal elevation of the porch designed for campus entrance.

The modeling of natural elements has been a challenge faced by the team. The first activity carried out in the research was to photograph all the built and natural elements present today. The natural elements were identified and represented in a series of schematic drawings in order to systematize the characteristics (Fig. 09). There were elaborated: a top view based on a digital image captured by a drone; a top view with species numbered; a top view with height indication; a numbering and an identification of species in the photographs. Additionally, we prepared a spreadsheet with the identification of plant species, including the following information: species name, popular name, description, uses, cultivation system, height, crown diameter, photograph, and source of information. 


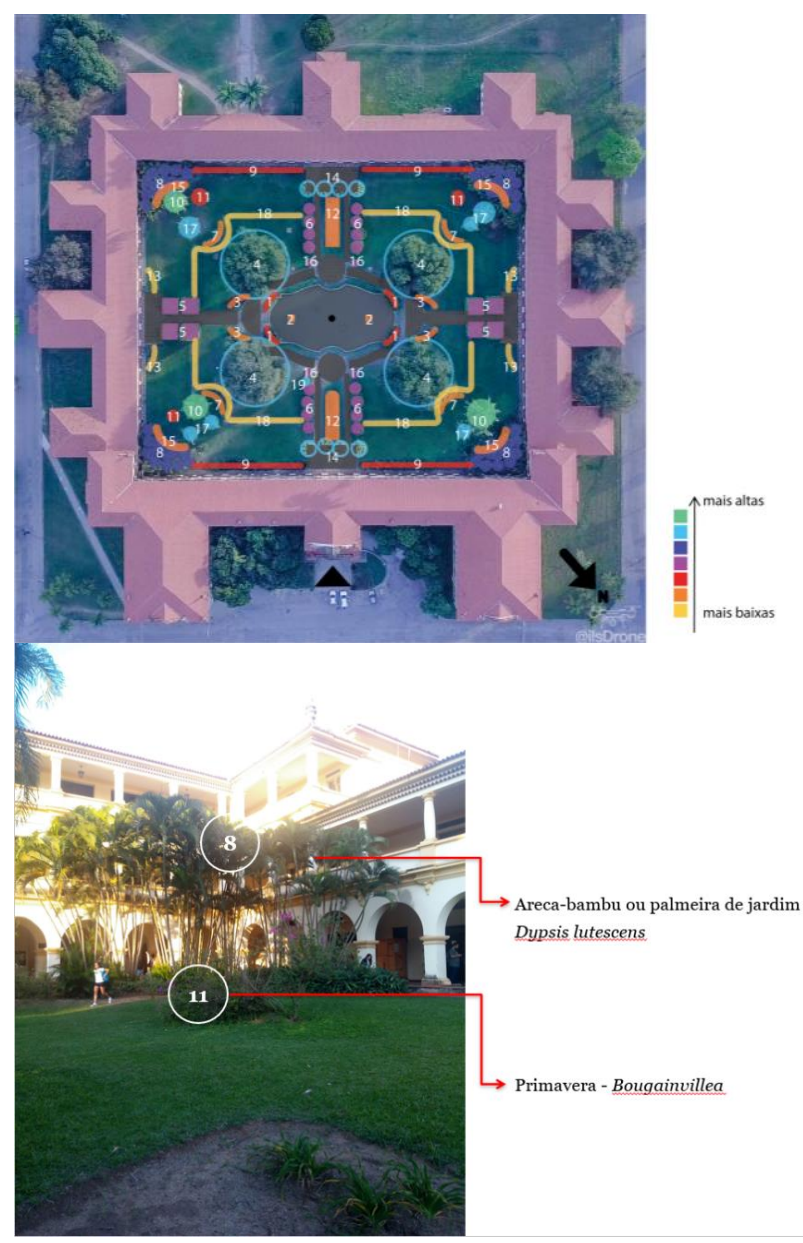

Figure 09. Above: Top view - central garden of the Central Pavilion. Numbered vegetation with heights. Below: photograph with species identification.

The biggest challenge of three-dimensional modeling of natural elements was to seek $3 \mathrm{~d}$ models of each specific species. The files available in vector formats usually do not identify the species they represent. Another challenge was to seek models of representation that would enable the visual identification of the characteristics of each species. This implies choosing the best level of detail in which the geometric model could be worked on low and medium-performance computers, using free modeling software (Trimble Sketchup).

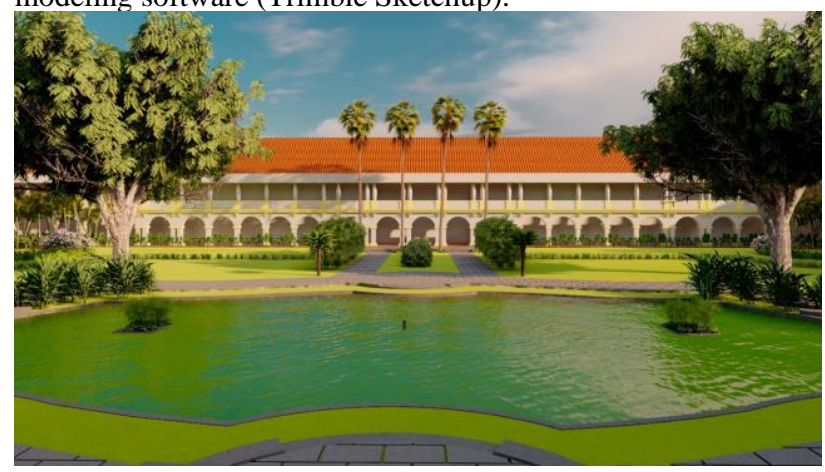

Figure 10. Three-dimensional modeling of the central garden of the Central Pavilion

The three-dimensional modeling of the buildings was carried out from the CAD drawings made available by NGS, and the photographs were taken by the team (Fig. 11).

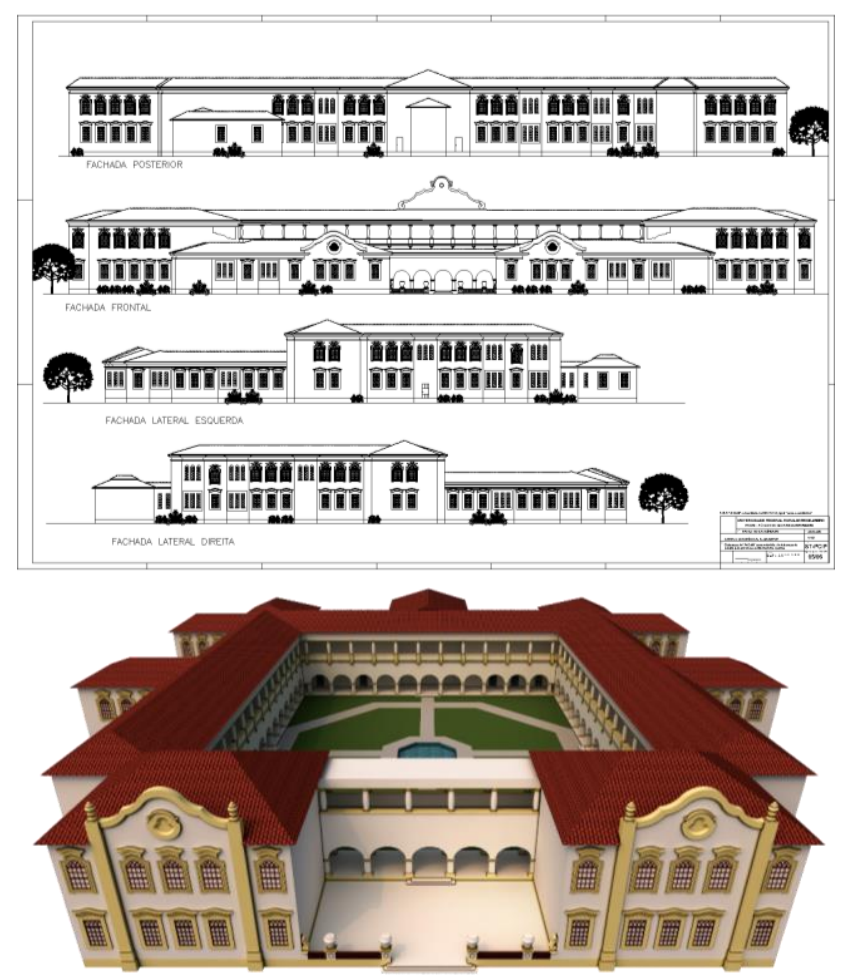

Figure 11. Above: CAD drawings of the Institute of Chemistry facades. Source: NGS / UFRRJ. Below: Three-dimensional modeling of the Institute of Chemistry.

\section{CONCLUSIONS}

The preliminary analysis of the drawings and watercolors available made possible the identification that Dierberger's original project was not completely built but partially executed. It suffered several changes since the inauguration of the campus, in 1948. These two conclusions reinforce the need for a conservation project based on this research.

Throughout the process, the importance of interdisciplinarity has been so necessary. Only the integration of different areas of knowledge made the interpretation of landscape design possible. Therefore, firstly, it was essential to understand aspects related to the theory of restoration, based on the parameters contained in the Letters of Venice (1964), Florence (1982), and Juiz de Fora (2010). Subsequently, knowledge of plant species was possible only because of the landscaping expertise of one member of the teamwork. Finally, the fundaments of the field of heritage documentation and graphic representation were necessary. The theoretical principles of the documentation were applied in different activities.

The building and the garden in front of the Agricultural Research Corporation of Rio de Janeiro - Pesagro - were not yet modeled, since we have not accessed the technical drawings of the project. It was not possible to carry out an on-site survey due to restrictions caused by mobility problems faced by the team during the COVID-19 pandemic.

The two gardens designed for the entrance of the Central Pavilion and the Pesagro buildings, which are opposite to each other on the axis of the main entrance, feature characteristic elements of the neocolonial language, as well as the surrounding buildings. The visual integration of the whole reinforced by porch design with a smaller scale would provide greater integration between the two areas of the campus, separated by the BR 465 Highway (formerly Rio-São Paulo Road).

Some changes were observed on the internal gardens of the main buildings located on the monumental axis of the campus: 
Central Pavilion (P1), Institute of Biology (IB), and Chemistry Pavilion (IC). We observed the replacement of some plant species by another, disrespecting the principles of the Letters of Florence (1982) and Juiz de Fora (2010), interpreting the comparison between drawings and photos from the time of construction with the drawings of the original buildings project. The lack of a preventive conservation plan for the campus garden and landscape also contributes to the progressive compromise of its integrity. It is estimated that, based on the documentary value of this research, added to other sources of information, it is possible to support future restoration interventions and the formulation of conservation strategies for this valuable landscape set built in the Seropédica campus of UFRRJ.

\section{REFERENCES}

Araujo, Ana Paula R., 2012: O ensino de expressãorepresentação gráfica e a apresentação nos Trabalhos Finais de Graduação do Curso de Arquitetura e Urbanismo / Universidade Federal do Rio de Janeiro. Tese (Doutorado em Arquitetura) Programa de Pós-Graduação em Arquitetura - PROARQ/UFRJ, Rio de Janeiro.

Arquivo Nacional (Brasil), 2001. Conselho Nacional de Arquivos. Classificação, temporalidade e destinação de documentos de arquivo relativos às atividades-meio da administração pública. Rio de Janeiro: Arquivo Nacional.

Arquivo Nacional (Brasil), 2010. Conselho Nacional de Arquivos. Resolução no 31 de abril de 2010. Dispõe sobre a adoção de recomendações para digitalização de documentos arquivísticos permanentes e Anexo: Recomendações para digitalização de documentos arquivísticos permanentes. Rio de Janeiro: Arquivo Nacional.

Barbin, H. S. 1999. Estudo das transformações na conformação dos maciços arbóreo/arbustivos do parque da Escola Superior de Agricultura "Luiz de Queiroz" através de fotografias aéreas verticais e levantamentos florísticos de épocas distintas, Dissertação de mestrado em Agronomia, Universidade de São Paulo, Piracicaba.

Boutinet, Jean-Pierre, 2002. Liminar: do Conceito ao Paradigma. In: Antropologia do Projeto. Porto Alegre: Artmed, p. $23-60$

Denard, Hugh, 2009. London Charter. For the computer-based visualisation of cultural heritage. version 2.1. London: King's College London.

Ferreira, Aurélio B. H. 1985. Dicionário da Língua Portuguesa. Rio de Janeiro: Editora Nova Fronteira.

Gruszynski, Ana Claudia, 2007. A imagem da palavra: retorica tipográfica na pós-modernidade. Teresópolis, RJ: Novas ideias, 203p. ISBN 9788560284047 (broch.)

International Forum of Virtual Archeology. 2011. Principles of Seville. International Principles of Virtual Archeology. Final Draft.

Lima Carlos, Claudio Antônio S. 2019. Quando o moderno era neocolonial: a participação de Eugênio de Proença Sigaud na construção do campus da Universidade Federal Rural do Rio de Janeiro. In: $3^{\circ}$ Congresso Internacional de história da construção Luso-brasileira, 2019, Salvador. Anais do $3^{\circ}$ CIHCLB.
Salvador: Núcleo de Tecnologia da Preservação e da Restauração, 2019. v. 1. p. 1622-1635.

Lima Carlos, Claudio Antônio S.; MARCONDES, P.; SOUZA, T. Y. 2019. Criação do laboratório de conservação de documentos da UFRRJ (LABDOC/UFRRJ): Memória, conservação e produção de conhecimentos. In: Rachel Myrrha de Paula Silva Neves; Vânia Myrrha de Paula Silva. (Org.). Estudos brasileiros sobre patrimônio. Volume 1. 1ed.Belo Horizonte: Poisson, 2019, v. 1, p. 222-232.

Lima Carlos, Claudio Antônio S. 2016. A memória do neocolonial brasileiro presente no acervo documental da construção do Campus da Universidade Federal Rural do Rio de Janeiro (UFRRJ). In: Congresso Ibero-Americano: património, suas matérias e imatérias, 2016, Lisboa. Congresso IberoAmericano: património, suas matérias e imatérias. Lisboa: LABORATÓRIO NACIONAL DE ENGENHARIA CIVIL, I.P., 2016. v. 1. p. 1-16.

Luesch-reis, Antônio M., 1991. Comunicação didática e design. In: SENAC. Boletim técnico do SENAC. RJ, p. 85- 106.

Moles, Abraham, 1979. O cartaz. São Paulo: USP, p.93-97

Sainz, Jorge, 2005. El dibujo de arquitectura: teoria e história de un lenguage gráfico. $2^{\mathrm{a}}$ ed. Barcelona: Reverté.

Terra, Carlos, 2013. Paisagens construídas. Jardins, praças e parques do Rio de Janeiro na segunda metade do século XIX. Rio de Janeiro: Rio Books.

Tostrup, Elisabeth, 1999. Architecture and Rhetoric. Text and Design in Architectural Competitions, Oslo, 1939- 1997. Londres: Andreas Papadaskis Pub., p. 23-28 